\title{
Systemic lupus erythematosus and pulmonary arterial hypertension: links, risks, and management strategies
}

\section{Konstantinos Tselios Dafna D Gladman Murray B Urowitz}

University of Toronto Lupus Clinic, Centre for Prognosis Studies in the Rheumatic Diseases, University Health Network, Toronto, ON, Canada
Correspondence: Murray B Urowitz University of Toronto Lupus Clinic, Centre for Prognosis Studies in the Rheumatic Diseases, University Health Network, 399 Bathurst St. IE-4IOB,

Toronto, ON M5T 2S8, Canada

Tel +l 4166035828

Fax+l 4166029387

Emailm.urowitz@utoronto.ca
This article was published in the following Dove Press journal:

Open Access Rheumatology: Research and Reviews

20 December 2016

Number of times this article has been viewed

\begin{abstract}
Systemic lupus erythematosus (SLE) is characterized by the second highest prevalence of pulmonary arterial hypertension (PAH), after systemic sclerosis, among the connective tissue diseases. SLE-associated PAH is hemodynamically defined by increased mean pulmonary artery pressure at rest ( $\geq 25 \mathrm{mmHg}$ ) with normal pulmonary capillary wedge pressure $(\leq 15 \mathrm{mmHg})$ and increased pulmonary vascular resistance. Estimated prevalence ranges from $0.5 \%$ to $17.5 \%$ depending on the diagnostic method used and the threshold of right ventricular systolic pressure in studies using transthoracic echocardiogram. Its pathogenesis is multifactorial with vasoconstriction, due to imbalance of vasoactive mediators, leading to hypoxia and impaired vascular remodeling, collagen deposition, and thrombosis of the pulmonary circulation. Multiple predictive factors have been recognized, such as Raynaud's phenomenon, pleuritis, pericarditis, anti-ribonuclear protein, and antiphospholipid antibodies. Secure diagnosis is based on right heart catheterization, although transthoracic echocardiogram has been shown to be reliable for patient screening and follow-up. Data on treatment mostly come from uncontrolled observational studies and consist of immunosuppressive drugs, mainly corticosteroids and cyclophosphamide, as well as PAH-targeted approaches with endothelin receptor antagonists (bosentan), phosphodiesterase type 5 inhibitors (sildenafil), and vasodilators (epoprostenol). Prognosis is significantly affected, with 1 - and 5-year survival estimated at $88 \%$ and $68 \%$, respectively.
\end{abstract}

Keywords: systemic lupus erythematosus, pulmonary arterial hypertension, immunosuppressive, transthoracic echocardiogram, endothelin receptor antagonists

\section{Introduction}

Pulmonary arterial hypertension (PAH) is classified into five distinct categories according to etiology. ${ }^{1}$ Group 1 PAH may be idiopathic, heritable, or drug or toxin induced, or it could be associated with human immunodeficiency virus, schistosomiasis, portal hypertension, and congenital heart disease as well as with connective tissue diseases (CTDs). PAH related to left heart diseases is classified in group 2, lung diseases in group 3, chronic thromboembolic pulmonary hypertension in group 4, while other, less well-known causes are included in group 5. CTD-associated PAH is hemodynamically defined by increased mean pulmonary artery pressure at rest (mPAP $\geq 25 \mathrm{mmHg}$ ), with normal pulmonary capillary wedge pressure (PCWP $\leq 15 \mathrm{mmHg}$ ) and increased pulmonary vascular resistance (PVR). ${ }^{2}$ Systemic lupus erythematosus (SLE) is characterized by the second highest prevalence of PAH, after systemic sclerosis, according to the REVEAL registry (Registry to Evaluate Early and Long-term Pulmonary Arterial Hypertension disease management), a 55-center longitudinal US-based registry with nearly 3,500 patients. $^{3}$ The aim of this review is to present the current knowledge on 
the epidemiology, pathophysiology, diagnosis and treatment of SLE-associated PAH (SLE-PAH).

\section{Epidemiology}

The annual incidence of systemic-autoimmune-diseaseassociated PAH has been estimated to be between one and three cases per million population, with a prevalence ranging from 5 to 15 cases per million. ${ }^{4,5}$ Cohort studies have reported that PAH prevalence in SLE varies widely between $0.5 \%$ and $43 \%,{ }^{6-8}$ although more recent reports estimate this as being between $0.5 \%$ and $17.5 \% .{ }^{9}$ Other investigators estimated the prevalence of $\mathrm{PAH}$ to be $14 \%$ based on the first transthoracic echocardiogram (TTE) of lupus patients. ${ }^{10}$ The differences are mainly attributed to the method used for diagnosis (TTE vs right heart catheterization, RHC), the threshold for $\mathrm{PAH}$ (right ventricular systolic pressure, RVSP $>30 \mathrm{mmHg}$ or $>40 \mathrm{mmHg}$ ), and the studied population.

The majority of patients with SLE-PAH are women (95\% in the REVEAL registry with RHC confirmed disease) with a mean age of 45 years $(45.5 \pm 11.9)$ at PAH diagnosis. ${ }^{11}$ In rare cases, PAH is the first manifestation leading to SLE diagnosis. ${ }^{12}$ Concerning severity, this is usually moderate with pulmonary artery systolic pressure (PASP) ranging between 40 and $60 \mathrm{mmHg}$ and PVR between 5 and 15 Wood units. ${ }^{11,13}$

\section{Predictive factors}

Certain lupus manifestations and immunologic abnormalities have been identified as predictors of PAH in observational cohort studies. In this context, Raynaud's phenomenon, active renal disease, and vasculitic manifestations (digital gangrene, cutaneous vasculitis, and livedo reticularis) were shown to independently predict PAH development. ${ }^{14,15}$ In another small prospective study with 34 patients, Raynaud's phenomenon was strongly related to increased PASP as assessed by TTE. ${ }^{16}$ Pleural effusions were also demonstrated to occur with higher frequency in CTD-associated PAH; patients with pleural effusions had higher mean right atrial pressure (mRAP) and lower cardiac output. ${ }^{17}$ However, most patients in that study had overt right heart failure, which may have contributed to pleural effusion. In a recent analysis of a large Chinese cohort ( $n=1,934,74$ patients with PAH), pleuritis was an independent predictor of PAH in lupus and showed an odds ratio $(\mathrm{OR})=3.06$ (95\% confidence interval $[\mathrm{CI}]=1.6-5.85) .{ }^{18}$ Additional clinical manifestations with an independent predictive ability for $\mathrm{PAH}$ were interstitial lung disease $(\mathrm{OR}=17,95 \% \mathrm{CI}=3.6-80)$ and pericardial effusion $(\mathrm{OR}=21.3,95 \% \mathrm{CI}=4.1-110.6) .{ }^{13}$ In the same study, it was shown that, paradoxically, lupus patients with PAH had less severe disease, as assessed by the SLE Disease Activity Index (SLEDAI); actually, a SLEDAI $\leq 9$ was strongly predictive of $\mathrm{PAH}$ with an $\mathrm{OR}=26.4(95 \% \mathrm{CI}=6.6-105.5) .{ }^{13}$ Moreover, the lack of acute rash and low erythrocyte sedimentation rate ( $\leq 20 \mathrm{~mm} / \mathrm{h}$ ) were also independent predictors. The clinical significance of these findings is difficult to interpret since it is believed that systemic inflammation drives PAH in these patients. $^{18}$

Immunological variables associated with $\mathrm{PAH}$ in lupus patients include positive anti-U1-RNP (ribonuclear protein) and antiphospholipid antibodies. ${ }^{13}$ Anti-U1-RNP antibodies, in particular, were strong predictors for PAH in several studies with a hazard ratio ranging from 2.6 to $12.4(95 \%$ $\mathrm{CI}=3.6-42.9) .{ }^{12,13,18}$ Antiphospholipid antibodies, mainly anticardiolipin antibodies and lupus anticoagulant, were also associated with increased risk for PAH. ${ }^{6,13,19}$ Recently, anti-Sjogren's Syndrome related antigen A antibodies were demonstrated as strong predictors with an $\mathrm{OR}=4.8$ $(95 \%$ CI $=1.7-14) .{ }^{13}$ Details on the predictive factors for $\mathrm{PAH}$ in lupus patients are given in Table 1.

\section{Pathogenesis}

The pathogenetic mechanisms in SLE-PAH have not been elucidated yet. However, accumulating evidence suggests

Table I Independent predictors of PAH in SLE

\begin{tabular}{|c|c|c|c|c|}
\hline Variable & Patients (n) & Hazard ratio & $95 \% \mathrm{Cl}$ & Reference \\
\hline Disease duration & 111 & 1.12 & $1.03-1.21$ & Huang et $\mathrm{al}^{13}$ \\
\hline Raynaud's phenomenon & 41 & 3.204 & $1.291-7.949$ & Lian et $\mathrm{al}^{14}$ \\
\hline Pleuritis & 74 & 3.061 & $1.602-5.85$ & $\mathrm{Li}$ et $\mathrm{a}^{18}$ \\
\hline \multirow[t]{2}{*}{ Pericarditis } & 111 & 21.3 & $4.1-110.6$ & Huang et $\mathrm{al}^{13}$ \\
\hline & 74 & 4.248 & $2.26 I-7.98$ & Li et al ${ }^{18}$ \\
\hline Interstitial lung disease & III & 17.03 & $3.6-80$ & Huang et $\mathrm{al}^{13}$ \\
\hline \multirow[t]{3}{*}{ Anti-RNP antibodies } & 111 & 12.4 & $3.6-42.9$ & Huang et $\mathrm{al}^{13}$ \\
\hline & 74 & 2.559 & $1.312-4.993$ & Li et $\mathrm{al}^{18}$ \\
\hline & $4 I$ & 5.393 & $2.073-14.028$ & Lian et $\mathrm{al}^{14}$ \\
\hline Anti-SSA/Ro antibodies & 111 & 4.84 & $1.7-14$ & Huang et $\mathrm{al}^{13}$ \\
\hline Anticardiolipin antibodies & 41 & 3.753 & $1.532-9.197$ & Lian et $\mathrm{al}^{14}$ \\
\hline
\end{tabular}

Abbreviations: $\mathrm{Cl}$, confidence interval; PAH, pulmonary arterial hypertension; RNP, ribonuclear protein; SLE, systemic lupus erythematosus; SSA/Ro, Sjogren's Syndrome related antigen $A$. 
that multiple factors, such as genetic predisposition, environmental stimuli, and immune system dysfunction play a significant role. ${ }^{15}$ The net result is an imbalance between vasoconstrictive and vasodilating soluble mediators, which leads to vasoconstriction with increased PVR. ${ }^{20}$ Endothelin-1 (ET-1) and thromboxane A2 (TXA-2) are the main mediators that lead to vasoconstriction; their serum levels were significantly elevated in patients with SLE-PAH and correlated with PAH severity. ${ }^{21,22}$ In addition, about $42 \%$ of patients with SLE-PAH were found to have antibodies against the endothelin receptor type A; their titers correlated strongly with PASP. ${ }^{23}$ These antibodies promote endothelial dysfunction and probably contribute to the inhibition of prostacyclin production by endothelial cells, which is one of the main vasodilators. ${ }^{15,20}$ In line with the vasoconstriction theory, it was recently demonstrated that lupus patients with $\mathrm{PAH}$ have increased arterial stiffness (assessed by brachial-ankle pulse wave velocity), and this was an independent predictor of PAH. ${ }^{24}$ Vasoconstriction represents an early event in the PAH pathogenic cascade, and vasoresponders (patients with a $>10 \mathrm{mmHg}$ decrease in PASP upon inhalation of vasoactive compounds during RHC) have a good response to calcium channel blockers, regardless of PAH etiology. ${ }^{25,26}$

Pulmonary vasoconstriction will lead to decreased oxygen saturation and hyperexpression of the hypoxia-inducible factor (HIF) and erythropoietin (EPO), which may promote smooth muscle cell proliferation and extensive vascular remodeling. ${ }^{20,27}$ Several distinct pathways are implicated in vascular remodeling such as impaired apoptosis with upregulation of antiapoptotic proteins and abnormal proliferation of endothelial and adventitial cells. ${ }^{15,20}$ In parallel, the inflammatory response will drive the accumulation of monocytes, neutrophils, mast cells, and dendritic cells into the elastic lamina, which in turn induce the production of certain chemokines, cytokines, and growth factors that perpetuate abnormal remodeling. ${ }^{28}$ In later stages of $\mathrm{PAH}$, microthrombi in the pulmonary vasculature will lead to further elevation of PASP. ${ }^{20}$

In the aforementioned pathogenetic model of $\mathrm{PAH}$, many characteristics of SLE, such as vasculitis, thrombosis, and interstitial pulmonary fibrosis are implicated. ${ }^{15}$ Pulmonary vasculitis is mediated through immune complexes; both immunoglobulins and complement have been demonstrated to deposit on the arterial wall. ${ }^{29}$ Other pulmonary vascular pathologic findings were similar to those of idiopathic PAH and mainly consisted of plexiform lesions, smooth muscle cell hypertrophy, intimal proliferation, and collagen deposition. ${ }^{15,30}$ In addition, CTD-associated
PAH was characterized by more frequent involvement of pulmonary veins and perivascular inflammatory infiltration. ${ }^{31}$ Thrombosis occurs more frequently in lupus patients, particularly in the presence of antiphospholipid antibodies. Although antiphospholipid syndrome per se may lead to chronic thromboembolic pulmonary hypertension, antiphospholipid antibodies have been shown to mediate endothelial dysfunction and induce the secretion of adhesion molecules. ${ }^{15}$ This may also occur in the presence of anti-endothelial cell antibodies - their binding to endothelial cells results in increased production of IL-6 and IL- $8 .^{32}$ The role of other immunological abnormalities in SLE-PAH, such as the decreased numbers of T regulatory cells and the more frequent presence of the anti-U1-RNP antibodies, has not been clarified yet. ${ }^{15,33} \mathrm{~A}$ schematic representation of the pathogenesis of $\mathrm{PAH}$ in the context of SLE is presented in Figure 1.

\section{Clinical presentation and diagnosis}

Dyspnea (initially exertional), dry cough, chest pain, exercise intolerance, and fatigue are the cardinal clinical manifestations of PAH. Physical findings may include elevated jugular venous pressure, accentuated S2 cardiac sound, and murmurs indicative of tricuspid and/or pulmonic valve insufficiency. In late stages, right heart failure with liver enlargement due to congestion, ascites, and/or lower limb edema may be seen.

The gold standard for PAH diagnosis is RHC, which precisely assesses PASP, diastolic PAP, PCWP, PVR, and cardiac output. ${ }^{1}$ Secure diagnosis requires a mean PAP $\geq 25 \mathrm{mmHg}$ at rest. ${ }^{34}$ Documentation of all these parameters also allows for rough etiologic characterization of PAH; a PCWP $\leq 15 \mathrm{mmHg}$ is required to exclude cases of heart failure. However, it was shown that many patients with heart failure and preserved ejection fraction have low PCWP (16-18 mmHg). ${ }^{35}$ PVR $\geq 3$ Wood units should also be included in the characterization of PAH. ${ }^{34}$ During the procedure, vasoreactivity can be assessed with the use of nitric oxide, epoprostenol, or adenosine. Most SLE patients are not vasoreactive, and therapy with calcium channel blockers has not proven to be beneficial. ${ }^{15} \mathrm{RHC}$ is not always feasible due to availability and/or procedure-related complications (mild-to-moderate in $1.1 \%$, mortality $0.055 \%$ ). ${ }^{36}$

TTE can provide a reliable estimation of the RVSP and tricuspid valve insufficiency. ${ }^{15}$ RVSP is calculated by the modified Bernoulli equation as RVSP $=4 v^{2}+$ mRAP, where $v$ equals the tricuspid regurgitant jet velocity (a reflection of the right ventricular-to-atrial systolic pressure gradient) 


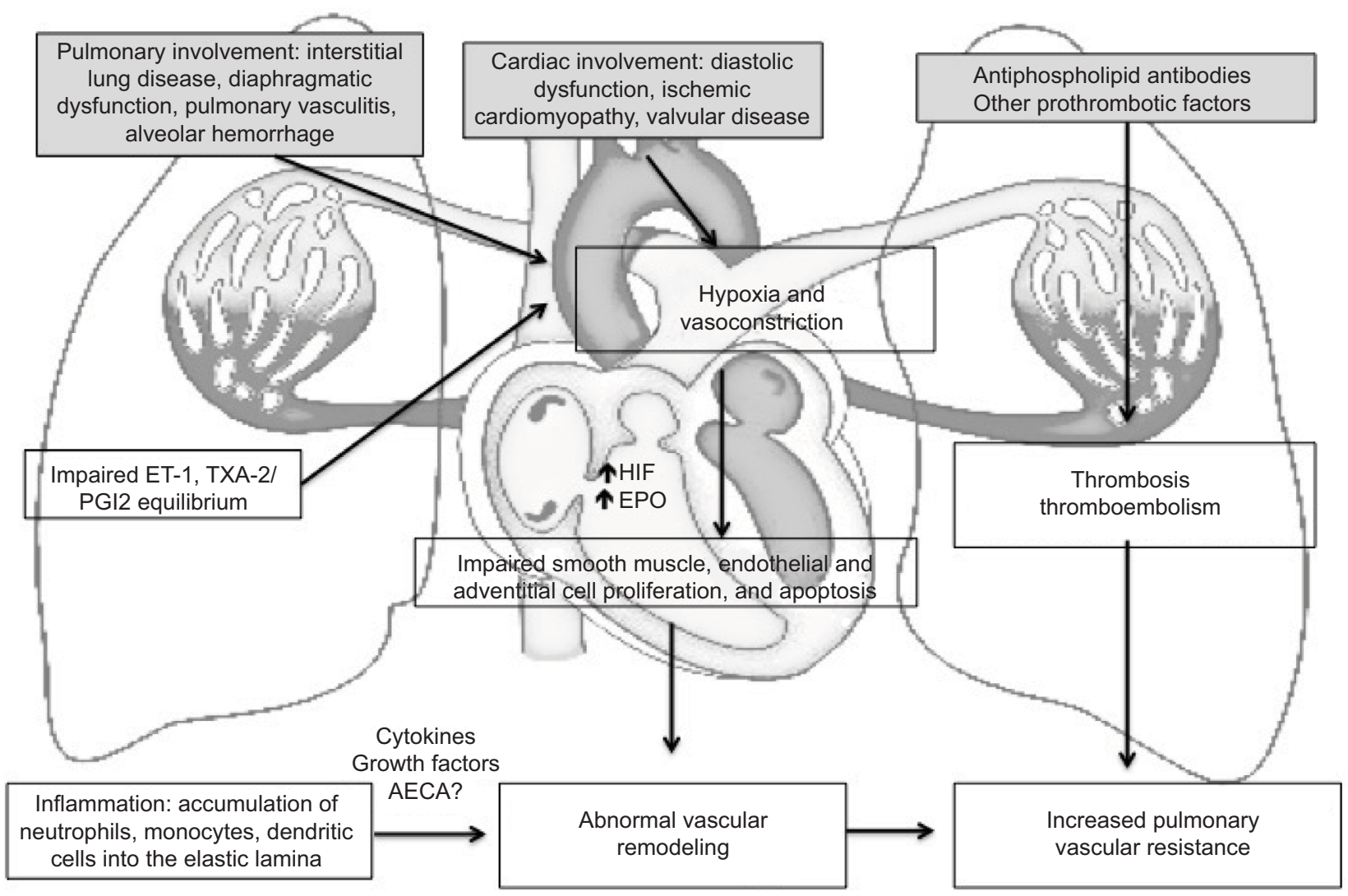

Figure I A schematic representation of the pathogenesis of PAH in SLE.

Notes: Pulmonary and cardiac involvement as well as disequilibrium between vasodilators (prostacyclin, PGI2) and vasoconstrictors (ET-I and, TXA-2) will lead to hypoxia and vasoconstriction. Hyperexpression of HIF and EPO will drive impaired smooth muscle, endothelial, and adventitial cell proliferation and apoptosis. In parallel, the accumulation of inflammatory cells into the elastic lamina of the pulmonary arteries and the secretion of certain cytokines and growth factors will lead to abnormal vascular remodeling, and thus increased PVR. In selected cases, thrombosis of the pulmonary circulation in the presence of antiphospholipid antibodies and other prothrombotic factors, will also contribute to increased PVR and PAH. The role of the anti-endothelial cell antibodies AECA and other immune mediators has not been clarified yet.

Abbreviations: PAH, pulmonary arterial hypertension; SLE, systemic lupus erythematosus; ET-I, endothelin-I; TXA-2, thromboxane A2; HIF, hypoxia-inducible factor; EPO, erythropoietin; PVR, pulmonary vascular resistance; AECA, anti-endothelial cell antibodies.

and mRAP is estimated from the diameter and respirophasic variability of the inferior vena cava during normal respiration. ${ }^{37}$ RVSP does not necessarily correlate with the measurement of PASP as obtained with RHC. ${ }^{38}$ In that study, TTE and RHC provided comparable measurements of PASP (77.2 $\pm 35 \mathrm{mmHg}$ vs $76.9 \pm 21.7 \mathrm{mmHg}$, respectively). However, TTE was inaccurate (over- or underestimating PASP by $>10 \mathrm{mmHg}$ ) in $57 \%$ of the cases. Other studies showed that the correlation between TTE and RHC was satisfactory, at least for the initial evaluation of such patients. ${ }^{39}$ Moreover, it was recently demonstrated that two consecutive TTEs with an RVSP $\geq 40 \mathrm{mmHg}$ were the most accurate predictors for PAH with a sensitivity of $100 \%$, specificity $97 \%$, positive predictive value of $70 \%$, and negative predictive value of $100 \%{ }^{40}$ In general, TTE is recommended for the initial screening of patients with suspected PAH as well as for the evaluation of response to treatment. ${ }^{34}$ Of note, TTE may lead to PAH diagnosis in asymptomatic patients, although the threshold used in that study was rather low $(\mathrm{RVSP}=30 \mathrm{mmHg}) .{ }^{41}$

Additional investigations are warranted for the precise etiologic diagnosis of PAH. High-resolution computed tomography of the thorax will help exclude any concomitant interstitial lung disease, while ventilation/perfusion scan for acute or chronic thromboemboli will rule out chronic thromboembolic pulmonary hypertension. ${ }^{15,34}$ Rare causes of PAH such as sleep apnea syndrome (assessed by polysomnography), human immunodeficiency virus, schistosomiasis, and portopulmonary hypertension should also be excluded. Pulmonary function tests reveal isolated decreased diffusing capacity for carbon monoxide $\left(\mathrm{D}_{\mathrm{LCO}}\right)$.

\section{Therapeutic approach}

Treatment of SLE-PAH should be prompt and aim at PASP normalization in order to maximize survival. Thorough diagnostic evaluation is of utmost importance since patients with 
no other risk factors (eg, left heart failure, chronic thromboembolic PAH) should be treated accordingly (diuretics, anticoagulants, etc). ${ }^{42}$ Existing randomized controlled trials have solely assessed the effect of PAH-targeted therapies with endothelin receptor antagonists (bosentan), phosphodiesterase type 5 inhibitors (PDE5 inhibitors, sildenafil), and vasodilators (treprostinil, a synthetic analog of prostacyclin, PGI2) ${ }^{43-45}$ In these studies, patients with different CTDs, mainly mixed connective tissue disease (MCTD) and systemic scleroderma, were also included, and a subanalysis of the lupus patients was not performed.

Additional data come from observational cohort studies using immunosuppressive therapies that have shown a considerable benefit in such patients. Tanaka et a ${ }^{46}$ reported a significant reduction of RVSP in seven out of eight patients who received corticosteroids \pm cyclophosphamide (CYC) two patients relapsed and were again treated successfully. Intravenous CYC pulses (dose ranging from $500 \mathrm{mg} / \mathrm{month}$ to $1,000 \mathrm{mg} / \mathrm{m}^{2} / \mathrm{month}$ ) were also administered in five cohort studies in conjunction with prednisone $(0.5-1 \mathrm{mg} / \mathrm{kg} /$ day with slow tapering $)^{47,48}$ and vasodilators ${ }^{49,50}$ or PDE5 inhibitors. ${ }^{51}$ Gonzalez-Lopez et $\mathrm{al}^{47}$ showed that CYC in combination with low doses of prednisone ( $<15 \mathrm{mg}$ /day) was effective in 16 patients with moderate SLE-PAH as assessed by TTE. In another study with CYC, five out of 12 lupus patients responded and showed improved survival. ${ }^{48}$ More recent studies demonstrated that the addition of vasodilators and supportive treatment with diuretics and anticoagulants may benefit patients with more severe PAH at diagnosis; in those studies, patients with MCTD were also included. ${ }^{49}$ Finally, Kommireddy et a ${ }^{51}$ reported a mean reduction of $16 \mathrm{mmHg}$ in PASP (assessed by TTE) with three intravenous CYC pulses plus oral prednisone and PDE5 inhibitors in 11/24 patients with SLE-PAH. Moreover, rituximab was shown to provide benefit in a refractory case of SLE-PAH, ${ }^{52}$ while another patient was successfully managed with mycophenolate mofetil and cyclosporine. ${ }^{12}$ Details on the studies that used immunosuppressive treatment for SLE-PAH are given in Table 2.

Other studies have used only PAH-targeted approaches in SLE-PAH. Robbins et $\mathrm{al}^{53}$ administered intravenous epoprostenol in six patients and observed a significant improvement in PAH hemodynamics and functional class according to the New York Heart Association. Other investigators reported similar results along with better survival in epoprostenol-treated patients. ${ }^{54}$ Oudiz et a ${ }^{45}$ showed a favorable hemodynamic response and trend toward improved quality of life in 25 lupus patients with subcutaneous treprostinil, a prostacyclin analog. Endothelin receptor antagonists, particularly bosentan, have been shown to improve functional New York Heart Association class and exercise tolerance (assessed with the 6-minute walk distance) in a randomized, placebo-controlled trial, which included 16 lupus patients, as well as other small observational studies. ${ }^{43,55,56}$ Moreover, sildenafil in low doses improved PAH hemodynamics and functional capacity after 12 weeks of treatment; in that study, 84 patients with CTD-associated PAH (19 with SLE) were subanalyzed. ${ }^{44}$ Finally, a randomized, placebo-controlled trial with riociguat, a soluble guanylate cyclase stimulator with vasoactive, antifibrotic, and anti-inflammatory effects, showed favorable results in PAH associated with CTDs. ${ }^{57}$ In that study, 18 patients with SLE were included; however, specific details for these patients were not provided. Details on the studies that used PAH-targeted therapies for SLE-PAH are given in Table 3.

\section{Prognosis}

PAH significantly affects survival and quality of life in CTDs. ${ }^{58}$ Direct comparisons from the REVEAL registry showed that patients with CTD-associated PAH had poorer 1-year survival as compared to patients with idiopathic PAH (86\% vs 93\%). ${ }^{11}$ Among the CTDs group, however, SLE patients had the best rates for 1-year survival ( $94 \%$ vs $82 \%$ for scleroderma and $88 \%$ for MCTD), although all patients had comparable hemodynamic characteristics at PAH diagnosis. Data from the Korean CTD-PAH registry, with 174 patients enroled, demonstrated that the 1- and 3-year survival were $90.7 \%$ and $87.3 \%$, respectively. ${ }^{59}$ In that study, low $\mathrm{D}_{\mathrm{LCO}}$, diabetes, and pleural effusion were poor prognostic factors, while anti-U1-RNP antibodies seemed to be protective. A recent meta-analysis of six studies encompassing 323 lupus patients with PAH demonstrated that the pooled 1-, 3-, and 5-year survival were $88 \%, 81 \%$, and $68 \%$, respectively ${ }^{60}$ Higher mPAP, PVR, and brain natriuretic peptide and lower 6-minute walk distance were related to poor survival. In an older systematic review of 23 observational studies, higher mPAP at diagnosis, Raynaud's phenomenon, thrombocytopenia, pregnancy, pulmonary vasculitis, and anticardiolipin antibodies were associated with decreased survival. ${ }^{61}$

\section{Conclusion}

PAH affects $0.5 \%-17.5 \%$ of patients with SLE and has significant effects on prognosis. Its pathogenesis is multifactorial and mediated through vasoconstriction, hypoxia, and impaired vascular remodeling. Immunosuppressive treatment 
Table 2 Studies with immunosuppressive medications for SLE-PAH

\begin{tabular}{|c|c|c|c|c|c|c|c|c|}
\hline Reference & Year & N (SLE) & Baseline & e characteristic & & Intervention & Outcome & $\begin{array}{l}\text { Notes/side } \\
\text { effects }\end{array}$ \\
\hline $\begin{array}{l}\text { Tanaka } \\
\text { et al }{ }^{46}\end{array}$ & 2002 & 12 & $\begin{array}{l}\text { Age } \\
\text { RVSP }\end{array}$ & $\begin{array}{l}38.3 \pm \mathrm{I} 4.2 \text { years } \\
55.5 \pm 10.7 \mathrm{mmH}\end{array}$ & & $\begin{array}{l}8 / 12 \text { received } \\
\text { corticosteroids } \\
\text { and/or } C Y C\end{array}$ & $\begin{array}{l}7 / 8 \text { responded (significant } \\
\text { decrease in RVSP), } 2 / 7 \\
\text { relapsed (treated with } \\
\text { corticosteroids plus CYC } \\
\text { successfully) }\end{array}$ & $\begin{array}{l}\text { Retrospective, } \\
\text { four patients had } \\
\text { SLE + SSc overlap } \\
\text { syndrome } \\
\text { One patient died } \\
\text { due to sepsis, } \\
\text { one developed } \\
\text { hemorrhagic cystitis }\end{array}$ \\
\hline $\begin{array}{l}\text { Gonzalez- } \\
\text { Lopez et al }{ }^{47}\end{array}$ & 2004 & 34 & $\begin{array}{l}\text { Age } \\
\text { mPASP }\end{array}$ & $\begin{array}{l}38 \pm \text { I I years } \\
39 \pm 6 \mathrm{mmHg}\end{array}$ & & $\begin{array}{l}\text { IV CYC }\left(500 \mathrm{mg} / \mathrm{m}^{2} /\right. \\
\text { month } \times 6 \text { months }) \mathrm{n}=16 \\
\text { vs } \\
\text { enalapril } 10 \mathrm{mg} / \text { day for } \\
6 \text { months, } \mathrm{n}=18 \\
+ \text { oral prednisone } \\
<15 \mathrm{mg} / \text { day }\end{array}$ & $\begin{array}{l}\text { I. Significant reduction in } \\
\text { PASP in both groups (I3 } \\
\mathrm{mmHg} \text { for CYC, } 8 \mathrm{mmHg} \\
\text { for enalapril) } \\
\text { 2. CYC performed better } \\
\text { in moderate PAH (initial } \\
\text { PASP }>35 \mathrm{mmHg} \text { ), } \\
\text { enalapril was not effective } \\
\text { 3. NYHA functional class } \\
\text { improved only with CYC }\end{array}$ & $\begin{array}{l}\text { Randomized } \\
\text { controlled trial, } \\
\text { PAH defined as } \\
\text { RVSP }>30 \mathrm{mmHg} \\
\text { by TTE } \\
\text { Patients on CYC } \\
\text { had more infections } \\
\text { and gastrointestinal } \\
\text { side effects }\end{array}$ \\
\hline $\begin{array}{l}\text { Sanchez } \\
\text { et } \mathbf{a}^{48}\end{array}$ & 2006 & $28(12)$ & $\begin{array}{l}\text { Age } \\
\text { mPAP } \\
\text { PVR } \\
\text { NYHA } \\
\text { 6MWD }\end{array}$ & $\begin{array}{l}29 \text { years } \\
54 \mathrm{mmHg} \\
19 \mathrm{WU} \\
\text { II, III } \\
370 \mathrm{~m}\end{array}$ & & $\begin{array}{l}\text { IV CYC } \\
\left(600 \mathrm{mg} / \mathrm{m}^{2} / \text { month }\right. \\
\times 3 \text { months }) \\
+ \text { oral prednisone } \\
(0.5-1 \mathrm{mg} / \mathrm{kg} \text { for } 4 \text { weeks, } \\
\text { then slow tapering) } \\
22 / 28\end{array}$ & $\begin{array}{l}5 / I 2 \text { SLE patients } \\
\text { responded } \\
\text { (mPAP decreased from } \\
49 \pm 16 \text { to } 34 \pm I I \mathrm{mmHg} \text {, } \\
\text { PVR from } 15.6 \pm 4 \text { to } \\
10.1 \pm 4 \mathrm{WU} \text { ) } \\
\text { Responders had improved } \\
\text { survival ( } 100 \% \text { vs } 38 \% \text { at } \\
5 \text { years) }\end{array}$ & $\begin{array}{l}\text { Patients with } \\
\text { MCTD and SSc } \\
\text { were also included } \\
\text { Two of } 28 \text { patients } \\
\text { died due to sepsis; } \\
\text { minor side effects } \\
\text { (leukopenia, } \\
\text { thrombocytopenia) } \\
\text { were infrequent }\end{array}$ \\
\hline Jais et $\mathrm{a}^{49}$ & 2008 & $23(13)^{*}$ & $\begin{array}{l}\text { Age } \\
\text { mPAP } \\
\text { PVR } \\
\text { NYHA } \\
\text { 6MWD }\end{array}$ & $\begin{array}{l}\text { IS }=9 \\
3 I \pm I 0 \text { years } \\
48 \pm 12 \mathrm{mmHg} \\
8.6 \pm 3.5 \mathrm{WU} \\
\text { II, III } \\
347 \pm 80 \mathrm{~m}\end{array}$ & $\begin{array}{l}\mathrm{IS}+\mathrm{VD}=4 \\
38 \pm 9 \text { years } \\
58 \pm 10 \mathrm{mmHg} \\
I 4.3 \pm 1.3 \mathrm{WU} \\
\mathrm{III}, \mathrm{IV} \\
38 \mathrm{I} \pm 7 \mathrm{I} \mathrm{m}\end{array}$ & $\begin{array}{l}\text { IV CYC }\left(600 \mathrm{mg} / \mathrm{m}^{2} /\right. \\
\text { month } \times 6 \text { months }) \\
+ \text { oral prednisone } \\
(0.5-1 \mathrm{mg} / \mathrm{kg} \text { for } 4 \text { weeks, } \\
\text { then slow tapering) } \\
+ \text { VDs } \\
+ \text { supportive treatment } \\
\text { (diuretics, anticoagulants) }\end{array}$ & $\begin{array}{l}\text { I. Patients with less severe } \\
\text { PAH (NYHA class I or II) } \\
\text { may respond to IS alone } \\
\text { 2. Patients with more severe } \\
\text { disease may benefit from } \\
\text { the addition of VDs }\end{array}$ & $\begin{array}{l}\text { Patients with } \\
\text { MCTD were also } \\
\text { included in the } \\
\text { analysis } \\
\text { Only minor side } \\
\text { effects (leukopenia, } \\
\text { thrombocytopenia) } \\
\text { were reported }\end{array}$ \\
\hline $\begin{array}{l}\text { Miyamichi- } \\
\text { Yamamoto } \\
\text { et al }{ }^{50}\end{array}$ & 2011 & $13(7)$ & $\begin{array}{l}\text { Age } \\
\text { mPAP } \\
\text { PVR } \\
\text { NYHA } \\
\text { 6MWD }\end{array}$ & $\begin{array}{l}42 \pm 8 \text { years } \\
39.5 \pm 9.2 \mathrm{mmHg} \\
8.75 \pm 5.43 \mathrm{WU} \\
\mathrm{I}, \mathrm{II}, \mathrm{III} \\
442 \pm 54 \mathrm{~m}\end{array}$ & & $\begin{array}{l}\text { IV CYC ( } 500 \mathrm{mg} / \text { month } \\
\times 10 \text { months) } \\
+ \text { oral prednisone } \\
\text { (I mg/kg for I month, } \\
\text { then slow tapering) } \\
+ \text { VDs (more than one } \\
\text { could be used in a single } \\
\text { patient) }\end{array}$ & $\begin{array}{l}\text { I. mPAP significantly } \\
\text { decreased from } 39.5 \pm 9.1 \\
\text { to } 28.9 \pm 1 \text { I } \mathrm{mmHg} \\
\text { 2. PVR: trend for decrease } \\
(700 \pm 434 \text { to } 48 \mathrm{I} \pm 418 \\
\left.\text { dynes } \cdot \mathrm{sec} / \mathrm{cm}^{5}\right) \\
\text { 3. Improved long-term } \\
\text { prognosis }\end{array}$ & $\begin{array}{l}\text { Analysis for I3 } \\
\text { patients with CTDs. } \\
\text { Among seven } \\
\text { SLE patients, five } \\
\text { responded quickly } \\
\text { (in months) } \\
\text { Two patients } \\
\text { developed mild } \\
\text { liver dysfunction }\end{array}$ \\
\hline $\begin{array}{l}\text { Kommireddy } \\
\text { et a }\left.\right|^{51}\end{array}$ & 2015 & 24 & $\begin{array}{l}\text { Age } \\
\text { mPASP } \\
\text { NYHA } \\
\text { 6MWD }\end{array}$ & $\begin{array}{l}25.4 \pm 8 \text { years } \\
59.3 \pm 18.7 \mathrm{mmH} \\
\mathrm{I}, \mathrm{II}, \mathrm{III}, \mathrm{IV} \\
312 \mathrm{~m}\end{array}$ & & $\begin{array}{l}\text { IV CYC }(500-1,000 \\
\left.\mathrm{mg} / \mathrm{m}^{2} / \text { month } \times 3 \text { months }\right) \\
+ \text { oral prednisone } \\
(0.5-1 \mathrm{mg} / \mathrm{kg} \text { for } 4 \text { weeks, } \\
\text { then slow tapering }) \\
+ \text { PDE5 inhibitors in } \\
20 / 24\end{array}$ & $\begin{array}{l}\mathrm{II} / 24 \text { responders } \\
\text { PASP reduced } \\
\text { from } 59.3 \pm 18.7 \text { to } \\
43.3 \pm 20.9 \mathrm{mmHg} \text { at } \\
6 \text { months }\end{array}$ & $\begin{array}{l}\text { Retrospective, PAH } \\
\text { defined as RVSP } \\
>30 \mathrm{mmHg} \text { by TTE } \\
2 / 24 \text { deaths, one } \\
\text { from resistant PAH } \\
\text { and one from septic } \\
\text { shock }\end{array}$ \\
\hline
\end{tabular}

Note: *Within the 13 SLE patients of this study, 9 received immunosuppressive treatment and 14 vasodilators.

Abbreviations: IV, intravenous; mPAP, mean pulmonary artery pressure; SLE-PAH, SLE-associated PAH; SLE, systemic lupus erythematosus; PAH, pulmonary arterial hypertension; PDE5, phosphodi-esterase type 5 inhibitors; RVSP, right ventricular systolic pressure; CYC, cyclophosphamide; SSc, systemic sclerosis; PASP, pulmonary artery systolic pressure; mPASP, mean PASP; TTE, transthoracic echocardiogram; PVR, pulmonary vascular resistance; NYHA, New York Heart Association; IS, immunosuppressive; VD, vasodilator; 6MWD, 6-minute walk distance; MCTD, mixed connective tissue disease; WU, Woods units. 
Table 3 Studies with PAH-targeted therapy medications for SLE-PAH

\begin{tabular}{|c|c|c|c|c|c|c|c|}
\hline Reference & Year & $\mathbf{N}$ (SLE) & Baseline & characteristics & Intervention & Outcome & Notes/side effects \\
\hline $\begin{array}{l}\text { Robbins } \\
\text { et } \mathrm{a}^{53}\end{array}$ & 2000 & 6 & $\begin{array}{l}\text { Age } \\
\text { mPASP } \\
\text { PVR } \\
\text { NYHA }\end{array}$ & $\begin{array}{l}26-35 \text { years } \\
57 \pm 9 \mathrm{mmHg} \\
\mathrm{I} 4 \pm 7 \mathrm{WU} \\
\text { III, IV }\end{array}$ & IV epoprostenol & $\begin{array}{l}\text { Significant improvement in } \\
\text { hemodynamics (PAP reduced } \\
\text { by } 38 \pm 21 \% \text {, PVR reduced by } \\
58 \pm I 2 \% \text { ), and NYHA functional } \\
\text { class from III-IV to I-II for all } \\
\text { patients }\end{array}$ & SLE relapsed in one patient \\
\hline $\begin{array}{l}\text { Rubin } \\
\text { et } \mathrm{a}^{43}\end{array}$ & 2002 & $213(16)$ & $\begin{array}{l}\text { Age } \\
\text { mPAP } \\
\text { PVR } \\
\text { NYHA } \\
\text { 6MWD }\end{array}$ & $\begin{array}{l}49 \pm 16 \text { years } \\
55 \pm 16 \mathrm{mmHg} \\
I 2.7 \pm 8.5 \mathrm{WU} \\
\text { III, IV } \\
330 \pm 74 \mathrm{~m}\end{array}$ & Bosentan & $\begin{array}{l}\text { Significant improvement in } \\
\text { exercise capacity (6MWD } \\
\text { increased by } 36 \mathrm{~m} \text { in cases, } \\
\text { decreased by } 8 \mathrm{~m} \text { in controls), } \\
\text { NYHA functional class ( } 42 \% \text { in } \\
\text { bosentan group), and time to } \\
\text { clinical worsening }\end{array}$ & $\begin{array}{l}\text { Double-blind, placebo-controlled } \\
\text { trial } \\
\text { No significant differences in side } \\
\text { effects between groups }\end{array}$ \\
\hline $\begin{array}{l}\text { Oudiz } \\
\text { et }\left.\right|^{45}\end{array}$ & 2004 & $90(25)$ & $\begin{array}{l}\text { Age } \\
\text { mPASP } \\
\text { NYHA } \\
\text { 6MWD }\end{array}$ & $\begin{array}{l}54 \pm 2 \text { years } \\
52 \pm 2 \mathrm{mmHg} \\
\text { II, III, IV } \\
280 \pm 13 \mathrm{~m}\end{array}$ & SC treprostinil & $\begin{array}{l}\text { Improved exercise capacity } \\
(6 \mathrm{MWD} \text { increased by } 25 \mathrm{~m}) \text {, } \\
\text { dyspnea, hemodynamics (PVR } \\
\text { decreased by } 4 \pm 2 \mathrm{WU}) \text {, and } \\
\text { trend toward improved quality } \\
\text { of life }\end{array}$ & $\begin{array}{l}\text { Double-blind, placebo-controlled } \\
\text { trial } \\
\text { Patients with MCTD and SSc } \\
\text { were also included } \\
\text { Minor side effects (infusion site } \\
\text { pain) only }\end{array}$ \\
\hline Mok et al ${ }^{56}$ & 2007 & 4 & $\begin{array}{l}\text { Age } \\
\text { mPAP } \\
\text { PVR } \\
\text { NYHA } \\
\text { 6MWD }\end{array}$ & $\begin{array}{l}42 \pm 8 \text { years } \\
39.5 \pm 9.2 \mathrm{mmHg} \\
8.75 \pm 5.43 \mathrm{WU} \\
\mathrm{I}, \mathrm{II}, \mathrm{III} \\
442 \pm 54 \mathrm{~m}\end{array}$ & Bosentan & $\begin{array}{l}\text { 6MWD significantly improved } \\
\text { in } 3(+24.8 \mathrm{~m}), 6(+26.2 \mathrm{~m}) \\
9(+54 \mathrm{~m}) \text {, and } 12(+62.7 \mathrm{~m}) \\
\text { months }\end{array}$ & $\begin{array}{l}\text { Liver toxicity in one patient, PASP } \\
\text { assessed with TTE }\end{array}$ \\
\hline $\begin{array}{l}\text { Badesch } \\
\text { et } \mathrm{al}^{44}\end{array}$ & 2007 & $284(19)$ & $\begin{array}{l}\text { Age } \\
\text { mPAP } \\
\text { PVR } \\
\text { NYHA } \\
\text { 6MWD }\end{array}$ & $\begin{array}{l}53 \pm I 5 \text { years } \\
47 \pm I I \mathrm{mmHg} \\
10.1 \pm 5.5 \mathrm{WU} \\
\text { II, III, IV } \\
342 \pm 76 \mathrm{~m}\end{array}$ & $\begin{array}{l}\text { Sildenafil } 20,40 \text {, } \\
\text { or } 80 \mathrm{mg} / \mathrm{d}\end{array}$ & $\begin{array}{l}\text { Patients with CTD-associated } \\
\text { PAH had improved exercise } \\
\text { capacity ( } 6 \mathrm{MWD} \text { increased by } \\
42 \mathrm{~m} \text { in cases and decreased } \\
\text { by } 13 \mathrm{~m} \text { in controls), } \\
\text { hemodynamics, and NYHA } \\
\text { functional class ( } 29 \%-42 \% \\
\text { improvement, } 5 \% \text { for placebo) } \\
\text { after } 12 \text { weeks of treatment } \\
\text { with sildenafil } 20 \mathrm{mg} / \text { day }\end{array}$ & $\begin{array}{l}\text { I2-week double-blind study } \\
\text { (SUPER-I) } \\
\text { Subgroup analysis of } 84 \text { patients } \\
\text { with CTD-associated PAH } \\
\text { Patients with SSc and other CTDs } \\
\text { were also included in the analysis } \\
\text { No significant side effects }\end{array}$ \\
\hline $\begin{array}{l}\text { Shirai } \\
\text { et a }\left.\right|^{54}\end{array}$ & 2013 & $16(6)$ & $\begin{array}{l}\text { Age } \\
\text { mPAP } \\
\text { PVR } \\
\text { NYHA }\end{array}$ & $\begin{array}{l}43 \pm 14 \text { years } \\
56 \pm 9 \mathrm{mmHg} \\
21 \pm 9 \mathrm{WU} \\
\text { III, IV }\end{array}$ & IV epoprostenol & $\begin{array}{l}\text { mPAP ( } 26 \% \text { reduction from } \\
\text { baseline), PVR ( } 41 \% \text { reduction } \\
\text { from baseline), and functional } \\
\text { class were improved after } 6 \\
\text { months. Treated patients had } \\
\text { better survival (3-year survival } \\
55 \% \text { vs } 6 \% \text { ) }\end{array}$ & $\begin{array}{l}\text { Patients with MCTD and SSc } \\
\text { were also included } \\
\text { All patients had treatment-related } \\
\text { side effects (headache, flushing, } \\
\text { diarrhea) } \\
\text { Seven of I } 6 \text { patients had } \\
\text { catheter-related infections and } \\
\text { required admission }\end{array}$ \\
\hline
\end{tabular}

Abbreviations: IV, intravenous; PAP, pulmonary artery pressure; mPAP, mean PAP; PAH, pulmonary arterial hypertension; SLE-PAH, SLE-associated PAH; SLE, systemic lupus erythematosus; SC, subcutaneous; SSc, systemic sclerosis; PASP, pulmonary artery systolic pressure; mPASP, mean PASP; PVR, pulmonary vascular resistance; NYHA, New York Heart Association; 6MWD, 6-minute walk distance; CTD, connective tissue disease; MCTD, mixed CTD; TTE, transthoracic echocardiogram; WU, Woods units.

is efficacious in selected cases, while PAH-targeted therapies may provide additional benefit.

\section{Disclosure}

The authors report no conflicts of interest in this work.

\section{References}

1. Simonneau G, Gatzoulis MA, Adatia I, et al. Updated clinical classification of pulmonary hypertension. J Am Coll Cardiol. 2013; 62 (Suppl 25):D34-D41.
2. McLaughlin VV, Archer SL, Badesch BD, et al. ACCF/AHA 2009 Expert consensus document on pulmonary hypertension. A report of the American College of Cardiology Foundation Task Force on Expert Consensus documents and the American Heart Association developed in collaboration with the American College of Chest Physicians, American Thoracic Society Inc and the Pulmonary Hypertension Association. J Am Coll Cardiol. 2009;53:1573-1619.

3. McGoon MD, Miller DP. REVEAL: a contemporary US pulmonary arterial hypertension registry. Eur Respir Rev. 2012;21:8-18.

4. Peacock AJ, Murphy NE, McMurrey JJ, Caballero L, Stewart S. An epidemiological study of pulmonary arterial hypertension. Eur Respir J. 2007;30:104-109. 
5. Humbert M, Sitbon O, Chaouat A, et al. Pulmonary arterial hypertension in France: results from a national registry. Am J Resp Crit Care Med. 2006;173:1023-1030.

6. Prabu A, Patel K, Yee CS, et al. Prevalence and risk factors for pulmonary arterial hypertension in patients with lupus. Rheumatology (Oxford). 2009;48:1506-1511.

7. Simonson JS, Schiller NB, Petri M, Hellmann DB. Pulmonary hypertension in systemic lupus erythematosus. J Rheumatol. 1989;16:918-925.

8. Winslow TM, Ossinov MA, Fazio GP, Simonson JS, Redberg RF, Schiller NB. Five-year follow-up study of the prevalence and progression of pulmonary hypertension in systemic lupus erythematosus. Am Heart $J$. 1995;129:510-515.

9. Arnaud L, Agard C, Haroche J, Cacoub P, Piette JC, Amoura Z. Pulmonary arterial hypertension in systemic lupus erythematosus. Rev Med Interne. 2011;32:689-697.

10. Johnson SR, Gladman DD, Urowitz MB, Ibanez DD, Granton JT. Pulmonary hypertension in systemic lupus. Lupus. 2004;13:506-509.

11. Chung L, Liu J, Parsons L, et al. Characterization of connective tissue disease-associated pulmonary arterial hypertension from REVEAL: identifying systemic sclerosis as a unique phenotype. Chest. 2010;138:1383-1394.

12. Prete M, Fatone MC, Vacca A, Racanelli V, Perosa F. Severe pulmonary hypertension as the initial manifestation of systemic lupus erythematosus: a case report and review of the literature. Clin Exp Rheumatol. 2014;32:267-274.

13. Huang C, Li M, Liu Y, et al. Baseline characteristics and risk factors of pulmonary arterial hypertension in systemic lupus erythematosus patients. Medicine (Baltimore). 2016;95:e2761.

14. Lian F, Chen D, Wang Y, et al. Clinical features and independent predictors of pulmonary arterial hypertension in systemic lupus erythematosus. Rheumatol Int. 2012;32:1727-1731.

15. Dhala A. Pulmonary arterial hypertension in systemic lupus erythematosus: current status and future directions. Clin Dev Immunol. 2012;2012:854941.

16. Kasparian A, Floros A, Gialafos, E, et al. Raynaud's phenomenon is correlated with elevated systolic pulmonary arterial pressure in patients with systemic lupus erythematosus. Lupus. 2007;16:505-508.

17. Luo YE, Robbins IM, Karatas M, Brixey AG, Rice TW, Light RW. Frequency of pleural effusions in patients with pulmonary arterial hypertension associated with connective tissue diseases. Chest. 2011;140:42-47.

18. Li M, Wang Q, Zhao J, et al. Chinese SLE Treatment and Research Group (CSTAR) registry: II. Prevalence and risk factors of pulmonary arterial hypertension in Chinese patients with systemic lupus erythematosus. Lupus. 2014;23:1085-1091.

19. Xia YK, Tu SH, Hu YH, et al. Pulmonary hypertension in systemic lupus erythematosus: a systematic review and analysis of 642 cases in Chinese population. Rheumatol Int. 2013;33:1211-1217.

20. Huber LC, Bye H, Brock M, Swiss Society of Pulmonary Hypertension. The pathogenesis of pulmonary hypertension-an update. Swiss Med Wkly. 2015;145:w14202.

21. Lai YC, Potoka KC, Champion HC, Mora AL, Gladwin MT. Pulmonary arterial hypertension: the clinical syndrome. Circulation Res. 2014;115:115-130.

22. Shen JY, Chen SL, Wu YX, et al. Pulmonary hypertension in systemic lupus erythematosus. Rheumatology Int. 1999;18:147-151.

23. Guo L, Li M, Chen Y, et al. Anti-endothelin receptor type A autoantibodies in systemic lupus erythematosus-associated pulmonary arterial hypertension. Arthritis Rheumatol. 2015;67:2394-2402.

24. Lee JH, Im Cho K. Arterial stiffness, antiphospholipid antibodies and pulmonary arterial hypertension in systemic lupus erythematosus. J Cardiol. 2014;64:450-455.

25. Sitbon O. Long-term response to calcium channel blockers in idiopathic pulmonary arterial hypertension. Circulation. 2005;111:3105-3111.

26. Montani D, Savale L, Natali D, et al. Long-term response to calcium channel blockers in non-idiopathic pulmonary arterial hypertension. Eur Heart J. 2010;31:1898-1907.
27. Karamanian VA, Harhay M, Grant GR, et al. Erythropoietin up-regulation in pulmonary arterial hypertension. Pulm Circ. 2014;4:269-279.

28. Pullamsetti SS, Savai R, Janssen W, et al. Inflammation, immunological reaction and role of infection in pulmonary hypertension. Clin Microbiol Infect. 2011;17:7-14.

29. Sasaki N, Kamataki A, Sawai T. A histopathological study of pulmonary hypertension in connective tissue diseases. Allergol Int. 2011; 60:411-417.

30. Roncoroni AJ, Alvarez C, Molinas F. Plexogenic arteriopathy associated with pulmonary vasculitis in systemic lupus erythematosus. Respiration. 1992;59:52-56.

31. Dorfmuller P, Humbert M, Perros F, et al. Fibrous remodelling of the pulmonary venous system in pulmonary arterial hypertension associated with connective tissue diseases. Hum Pathol. 2007;38:893-902.

32. Arends SJ, Damoiseaux JG, Duijvestijn AM, et al. Functional implications of IgG anti-endothelial cell antibodies in pulmonary arterial hypertension. Autoimmunity. 2013;46:463-470.

33. Nicolls MR, Taraseviciene-Stewart L, Rai PR, Badesch DB, Voelkel NF. Autoimmunity and pulmonary hypertension: a perspective. Eur Respir J. 2005;26:1110-1118.

34. Hoeper MM, Bogaard HJ, Condliffe R, et al. Definitions and diagnosis of pulmonary hypertension. J Am Coll Cardiol. 2013;62 (Suppl 25): D42-D50.

35. Frost AE, Farber HW, Barst RJ, Miller DP, Elliott CG, McGoon MD. Demographics and outcomes of patients diagnosed with pulmonary hypertension with pulmonary capillary wedge pressures 16 to $18 \mathrm{mmHg}$ : insights from the REVEAL registry. Chest. 2013;143:185-195.

36. Hoeper MM, Lee SH, Voswinckel R, et al. Complications of right heart catheterization procedures in patients with pulmonary hypertension in experienced centres. J Am Coll Cardiol. 2006;48:2546-2552.

37. Kircher BJ, Himelman RB, Schiller NB. Noninvasive estimation of right atrial pressure from the inspiratory collapse of the inferior vena cava. Am J Cardiol. 1990;66:493-496.

38. Farber HW, Foreman AJ, Miller DP, Mcgoon MD. REVEAL Registry: correlation of right heart catheterization and echocardiography in patients with pulmonary arterial hypertension. Congest Heart Fail. 2011;17:56-64.

39. Rich JD, Shah SJ, Swamy RS, Kamp A, Rich S. Inaccuracy of Doppler echocardiographic estimates of pulmonary artery pressures in patients with pulmonary hypertension: implications for clinical practice. Chest. 2011;139:988-993.

40. Ruiz-Irastorza G, Garmendia M, Villar I, Egurbide MV, Aguirre C. Pulmonary hypertension in systemic lupus erythematosus: prevalence, predictors and diagnostic strategy. Autoimmun Rev. 2013;12:410-415.

41. Kamel SR, Omar GM, Darwish AF, Asklany HT, Ellabban AS. Asymptomatic pulmonary hypertension in systemic lupus erythematosus. Clin Med Insights Arthritis Musculoskelet Disord. 2011;4:77-86.

42. Akdogan A, Kilic L, Dogan I, et al. Pulmonary hypertension in systemic lupus erythematosus: pulmonary thromboembolism is the leading cause. J Clin Rheumatol. 2013;19:421-425.

43. Rubin LJ, Badesch DB, Barst RJ, et al. Bosentan therapy for pulmonary arterial hypertension. N Engl J Med. 2002;346:896-903.

44. Badesch DB, Hill NS, Burgess G, et al. Sildenafil for pulmonary arterial hypertension associated with connective tissue diseases. J Rheumatol. 2007;34:2417-2422.

45. Oudiz RJ, Schilz RJ, Barst RJ, et al. Treprostinil, a prostacyclin analogue, in pulmonary arterial hypertension associated with connective tissues disease. Chest. 2004;126:420-427.

46. Tanaka E, Harigai M, Tanaka M, Kawaguchi Y, Hara M, Kamatani M. Pulmonary hypertension in systemic lupus erythematosus: evaluation of clinical characteristics and response to immunosuppressive treatment. J Rheumatol. 2002;29:282-287.

47. Gonzalez-Lopez L, Cardona-Munoz EG, Celis A, et al. Therapy with intermittent pulse cyclophosphamide for pulmonary hypertension associated with systemic lupus erythematosus. Lupus. 2004;13: $105-112$. 
48. Sanchez O, Sitbon O, Jais X, Simonneau G, Humbert M. Immunosuppressive therapy in connective tissue diseases-associated pulmonary arterial hypertension. Chest. 2006;130:182-189.

49. Jais X, Launay D, Yaici A, et al. Immunosuppressive therapy in lupusand mixed connective tissue disease-associated pulmonary arterial hypertension: a retrospective analysis of twenty-three cases. Arthritis Rheum. 2008;58:521-531.

50. Miyamichi-Yamamoto S, Fukumoto Y, Sugimura K, et al. Intensive immunosuppressive therapy improves pulmonary hemodynamics and long-term prognosis in patients with pulmonary arterial hypertension associated with connective tissue disease. Circ J. 2011;75:2668-2674

51. Kommireddy S, Bhyravavajhala S, Kurimeti K, et al. Pulmonary arterial hypertension in systemic lupus erythematosus may benefit by addition of immunosuppression to vasodilator therapy: an observational study. Rheumatology (Oxford). 2015;54:1673-1679.

52. Hennigan S, Channick RN, Silverman GJ. Rituximab treatment of pulmonary arterial hypertension associated with systemic lupus erythematosus: a case report. Lupus. 2008;17:754-756.

53. Robbins IM, Gaine SP, Schilz R, Tapson VE, Rubin LJ, Loyd JE. Epoprostenol for treatment of pulmonary hypertension in patients with systemic lupus erythematosus. Chest. 2000;117:14-18.

54. Shirai Y, Yasuoka H, Takeuchi T, Satoh T, Kuwana M. Intravenous epoprostenol treatment of patients with connective tissue disease and pulmonary arterial hypertension at a single centre. Mod Rheumatol. 2013;23:1211-1220.
55. Denton CP, Humbert M, Rubin L, Black CM. Bosentan treatment for pulmonary arterial hypertension related to connective tissue disease: a subgroup analysis of the pivotal clinical trials and their open-label extensions. Ann Rheum Dis. 2006;65:1336-1340.

56. Mok MY, Tsang PL, Lam YM, Lo Y, Wong WS, Lau CS. Bosentan use in systemic lupus erythematosus patients with pulmonary arterial hypertension. Lupus. 2007;16:279-285.

57. Humbert M, Coghlan JG, Ghofrani HA, et al. Riociguat for the treatment of pulmonary arterial hypertension associated with connective tissue diseases: results from PATENT-1 and PATENT-2. Ann Rheum Dis. 2016. doi: 10.1136/annrheumdis-2015-209087.

58. Wang H, Guo X, Lai J, et al. Predictors of health-related quality of life in patients with systemic lupus erythematosus associated pulmonary arterial hypertension. Clin Exp Rheumatol. 2016;34:291-295.

59. Kang KY, Jeon $\mathrm{CH}$, Choi SJ, et al. Survival and prognostic factors in patients with connective tissue disease-associated pulmonary hypertension by echocardiography: results from a Korean nationwide registry. Int J Rheum Dis. 2015. doi: 10.1111/1756-185X.12645

60. Qian J, Wang Y, Huang C, et al. Survival and prognostic factors of systemic lupus erythematosus-associated pulmonary arterial hypertension: a PRISMA-compliant systematic review and meta-analysis. Autoimmun Rev. 2016;15:250-257.

61. Chow SL, Chandran V, Fazelzad R, Johnson SR. Prognostic factors for survival in systemic lupus erythematosus associated pulmonary hypertension. Lupus. 2012;21:353-364.
Open Access Rheumatology: Research and Reviews

\section{Publish your work in this journal}

Open Access Rheumatology: Research and Reviews is an international, peerreviewed, open access journal publishing original research, reports, editorials, reviews and commentaries on all aspects of clinical and experimental rheumatology in the clinic and laboratory including the following topics: Pathology, pathophysiology of rheumatological diseases; Investigation, treatment and

\section{Dovepress}

management of rheumatological diseases; Clinical trials and novel pharmacologi$\mathrm{cal}$ approaches for the treatment of rheumatological disorders. The manuscript management system is completely online and includes a very quick and fair peer-review system, which is all easy to use. Visit http://www.dovepress.com/ testimonials.php to read real quotes from published authors. 